\title{
DECISION ANALYSIS FOR CONSTRUCTION CONTRACT RISK-SHARING
}

\author{
Teh-Chang Lee \\ Department of Construction Engineering, National Taiwan University of Science and Technology, Taipei, Taiwan, \\ R.O.C. \\ Ta-Hsing Lee \\ Department of Construction Engineering, National Taiwan University of Science and Technology, Taipei, Taiwan, \\ R.O.C., daniel.lee@maaconsultants.com \\ Ching-Hwang Wang \\ Department of Construction Engineering, National Taiwan University of Science and Technology, Taipei, Taiwan, \\ R.O.C.
}

Follow this and additional works at: https://jmstt.ntou.edu.tw/journal

Part of the Civil and Environmental Engineering Commons

\section{Recommended Citation}

Lee, Teh-Chang; Lee, Ta-Hsing; and Wang, Ching-Hwang (2009) "DECISION ANALYSIS FOR CONSTRUCTION CONTRACT RISK-SHARING," Journal of Marine Science and Technology. Vol. 17: Iss. 2, Article 1.

DOI: 10.51400/2709-6998.1961

Available at: https://jmstt.ntou.edu.tw/journal/vol17/iss2/1

This Research Article is brought to you for free and open access by Journal of Marine Science and Technology. It has been accepted for inclusion in Journal of Marine Science and Technology by an authorized editor of Journal of Marine Science and Technology. 


\title{
DECISION ANALYSIS FOR CONSTRUCTION CONTRACT RISK-SHARING
}

\author{
Teh-Chang Lee*, Ta-Hsing Lee*, and Ching-Hwang Wang*
}

Key words: construction contract, risk-sharing, analytic hierarchy process, fuzzy synthetic decision.

\begin{abstract}
As the risk-sharing provisions in domestic public construction contracts are not completely fair and reasonable, contract disputes often arise as a result which in turn cause delays, quality impacts, and other problems that urgently need improvement. Introduced in this article is the development of a decision system for risk-sharing in public construction contracts. Said system was developed through literature review, questionnaire and interviews of experts, fuzzy synthetic evaluation in conjunction of analytic hierarchy process, definition of risks in public construction contracts, and establishment of decision models for risk-sharing. Subsequently, the "escalation" risk was employed as an example to select suitable decision models for analyzing risk-sharing decisions. The evaluation model of contract risk-sharing performance established in this article can be the basis for authority in its optimal risk-sharing decision-making.

According to result of decision analysis made in this article for risk of "rising price and wages," it is suggested that the authority shall select the sharing program of "adjust the portion with rising/falling amplitude exceeding (5\%) according to particular price index" for construction with duration exceeding 1 year. The authority is also suggested to set fair and reasonable contract that regulates rights and obligations for both parties with principle of equal and mutual benefit.
\end{abstract}

\section{PREFACE}

The fair and reasonable risk-sharing is helpful for smooth completion of construction, cost saving and prevention of contractual dispute. However, research and investigation [16, 18] have shown that in order to protect its own interests, construction authority in the past often made use of exceptions to exert most of the risks onto the contractors. Although the

Paper submitted 09/07/07; accepted 12/25/07. Author for Corresponding: Ta-Hsing Lee (e-mail: daniel.lee@maaconsultants.com).

*Department of Construction Engineering, National Taiwan University of Science and Technology, Taipei, Taiwan, R.O.C. authority can avoid the risk with such contract agreement that is lack of fairness, adverse effect can possibly arise due to the over provision and cause difficulty to undertaking personnel; moreover, it is found from many cases of arbitration [3] and mediation [10] that the authority may still need to compensate the contractor's loss due to breach for violating principle of fair and sincere contract. In addition, the increase of contract risk is not only incapable of stopping unworthy companies on vicious acquisition of tender, but also strangles willingness of tendering from honest companies, which forms the vicious circle of "bad elements driving good elements away" and hence no protection is provided on construction quality.

In order to improve the above mentioned defects, Article 6, Paragraph 2 of the "Government Procurement Act" particularly specifies that the authority shall base on the principle of maintenance on public interest and reasonable fairness upon setting of procurement contract. In Paragraph 3 of the same Article, power is given to the purchaser within the scope of not violating regulation of the Government Procurement Act, where such purchaser can base on the consideration for public interest, efficiency of procurement and professional judgment to decide on suitable procurement; in this way, efficiency and function of procurement can be improved as well as assurance on quality of procurement. Nevertheless, contractual amount and hidden risk involved in public construction are often vast and complicated, the selection on suitable decision making of risk-sharing is truly an important subject that is worth for discussion at present under principle of reasonable fairness; so that both contractual parties can bear affordable risks and thoroughly bring out their professional skills to pursue maximum profit for the overall construction.

In view of this, the article starts with brief description on connotation of risk-sharing decision for public construction contract. This follows logic of decision on risk-sharing to define risk of public construction contract and establish risk-sharing decision model, develop the "Risk-sharing decision system for public construction contract"; moreover, the recent risk of "escalation" that seriously affect execution of domestic public construction is taken as example for escalation of suitable decision model and execution on decision analysis relating to risk-sharing, which provides reference for the authority upon selection on risk-sharing decision and setting of contractual clauses. 


\section{STRUCTURE OF DECISION SYSTEM FOR PUBLIC CONSTRUCTION CONTRACT RISK-SHARING}

\section{Overview of Public Construction Contract Risk-Sharing}

The so-called "Public Construction Contract Risk-Sharing" discusses about suitable selection of risk-sharing decision model against various (each) construction contract risk and through adequate contract arrangement, risks within certain level and scope are distributed to owner and/or contractor that can deal with the risks in most economical and effective way. Various feasible measure of risk-sharing are offered to optimal adjustment of overall risk burden for both parties of the construction contract, which expects to obtain maximum benefit of procurement contract. In quoted words:

1. The priority of risk-sharing decision lies on selecting suitable way of classification; it executes systematic classification on each contract risk of project construction. Further analysis and definition is then made against the property of risk (possibility of forecast and prevent in advance) and characteristics of loss (individual and type of loss), which provides fundamentals of risk distribution.

2. The decision of risk-sharing does no go deep into method of handling the risk itself; instead, discussion is made on most "effective" way of handling the risk or selection for most "economical" way of sharing in accordance with the characteristics of the risk.

3. In addition to individual undertaking by certain part on lost of certain risk, there is still option on method of risk-sharing according to result of decision analysis:

(1) The loss from risk is shared by both parties at fixed amount and/or proportion.

(2) One party undertakes the loss from work duration and the other party undertakes loss in cost.

(3) One party is obliged to prevent or reduce occurrence or damage from the risk and the other party undertakes the actual loss from risk.

4. The authority can consider characteristics and budget of project construction, as well as resources and managing ability possessed by itself to discuss on feasible sharing measure of "risk reduction" and "finance benefit," which reduces financial (or risk) burden for the supplier and enhances supplier's ability of contract performance.

5. With adequate contract arrangement afterwards and under pre-requisite of not violating legal requirement, selected program of risk-sharing is carried out in practice via thorough and precise contractual requirement.

6. As for expected requisition of benefit on procurement contract from reasonable sharing of contract risk, such benefit is mainly provided for $[1,2,24]$ :

(1) Reminding the parties concerned to pay attention on rights and obligations of both parties under the contract, which enhances cost benefit of contract management.

(2) Reducing uncertainty of contract risk, which eliminates risk not necessary for both parties to undertake.
(3) Reducing fixed cost needed for undertaking the risk via reasonable sharing of contract risk by both parties.

(4) Promoting peaceful work relationships between both parties, which reduces contract dispute.

\section{Guideline of Risk-Sharing Decision}

According to result of discussion on relevant literature, the decision guideline relating to risk-sharing can be basically summarized as follows:

1. According to principle of "responsibility of mistake," the loss from risk is undertaken by responsible party.

2. With concept of "advantageous risk bearer" [7, 20], assessment is made on both parties of the contract for determining the party that has better ability of prevention, reduction, handling or transfer against occurrence of the risk, where the risk bearer is appointed accordingly.

3. Evaluate item that needs lower cost (compared price) of risk handling with the concept of "bargain insurer" $[7,20]$, or discuss on sharing method (or program) to be adopted, so both parties spend least amount of total cost for risk-sharing and the method can be taken as guideline for risk distribution.

4. Discuss on the type of risk-sharing program that can obtain best benefit of overall contract with consideration on "performance of risk-sharing," which can be taken as criterion of sharing decision [4].

However, the above guidelines only act as principle descriptions, the basis of assessment or evaluation and method of execution are still to be explored further. The following section will base on the above mentioned guidelines to establish qualitative or quantitative model for analysis decision, which provides reference for the authority while setting up the risk-sharing decision.

\section{Risk-Sharing Decision Model}

\section{1) Risk Liability Judgment Model}

\section{(I) Structure of Judgment}

The public construction contract is taken as the agreed contract and principles of civil contract adopted. Therefore, discussion shall be made first to see if the risk involves with liability for non-fulfillment of debt, tort liability and risk-bearing liability specified by "the Civil Code," as well as principles of honest credibility, fair reasonableness and changing situation for the contract while setting the risk-sharing decision. After that, risks are distributed in accordance with judgment result on liability of mistake with the structure of judgment shown as Fig. 1 below.

\section{(II) Consideration of Judgment}

In order to prevent invalid contract due to legal violation however, discussion is made on relevant regulation of project construction including: (1) Relevant regulations of construc- 


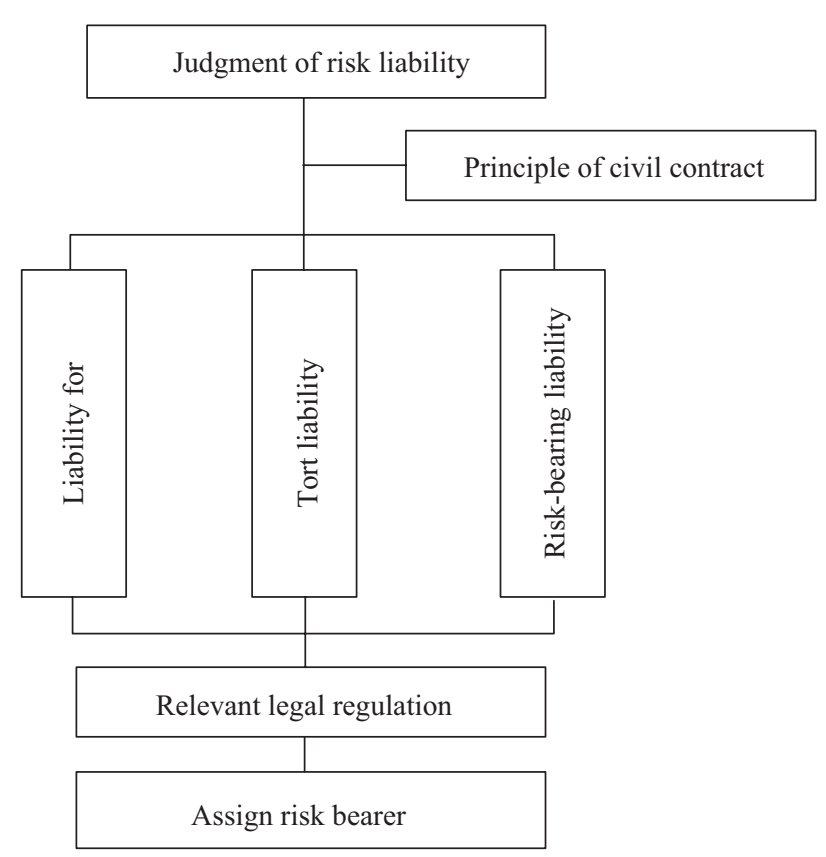

Fig. 1. Structure for judgment of contract risk liability.

tion procurement, (2) Relevant regulations of labor, safety, health and environment protection, (3) Particular construction regulations such as Highway Act, Railway Act and Mass Rapid Transportation Act for traffic engineering and see if there is special requirement on risk-sharing, which provides legal basis for obligation of distributing contract risk.

\section{2) Assessment Model on Risk Controlling Ability}

(I) Structure of Assessment

1. According to research recommendation made by Chou [8], Erikson [11], and $\mathrm{Ku}$ [14]:

(1) The risk bearer must be the participant in the construction and most capable of predict and prevent the risk.

(2) The risk bearer must be the party that can promptly deal with the risk via existing system and resources.

(3) The risk bearer must be the party that can deal with the risk with most economical and effect method.

2. In reference with the above mentioned principles, this article has compiled recommendation by Bunni [5], Lai [15] and result from interview with experts to set the structure of assessment for risk-controlling ability (as shown in Fig. 2), where the measurement of which party in the contract possess better influencing, controlling and handling ability can be taken as basis of risk distribution.

(1) The influencing ability discusses about actual participant or direct executor of relevant work. Such ability is used to measure the party that has greater power of influence on occurrence and handling of the risk.

(2) The controlling ability verifies the person that is more capable of dealing with the risk and evaluating probability of occurrence for such risk, as well as information channel on degree of influence.

(3) The handling ability measures the party that is more

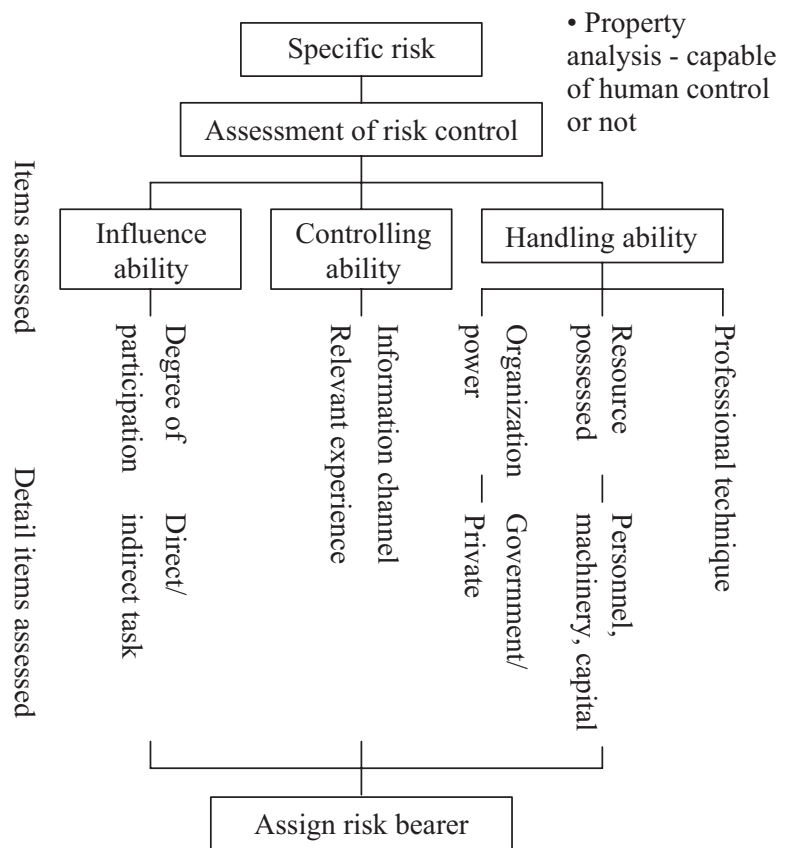

Fig. 2. Assessment structure for controlling ability of contract risk.

capable of handling the risk in most economical and effect way via existing system (government/private), relevant resources possessed (personnel, machinery and fund) and professional technique provided.

(II) Consideration and Steps of Assessment

1. Prior to assessment of risk controlling ability, investigation and evaluation must be carried out on following aspects first:

(1) Authority: Is it for general administration or professed in construction affairs? What are the information channel, man-power and budget possessed? How is the ability of plan management and past experience on dealing with relevant coordination?

(2) Relevant entity and related suppliers: What is the quantity of relevant entity, related suppliers and affairs to be cooperated for the project construction? How is the cooperating ability for other party and progress of relevant construction?

(3) Contractors: How is the qualification and scale of the contractor? What are the organizations, man-power, financial power, technology, and relevant resources of machinery and equipment that shall be possessed? What is the ability of program management that shall be provided? What is the similar experience of construction in the past?

2. As for the assessment on risk controlling ability, the following steps can be followed:

(1) Firstly, suitable items of assessment are selected against each contract risk.

(2) Secondly, measure and see which of the contracting party has better advantage of controlling the risk according to each assessing item. 
(3) Lastly, appoint the risk bearer according to result of assessment on each item.

\section{3) Evaluation Model for Risk-Sharing Cost}

(I) Evaluation Model

1. For relevant study overseas in the past:

(1) The "Risk Attitude Method of Analysis" established by Mason [22] applied cash flow analysis for combination with risk analysis of probability theory and utility analysis of decision maker, which calculates expected effect of cost needed on each risk treating methods (e.g. risk retention or transfer). According to this, most suitable policy of handling and contractual terms are selected.

(2) The "Construction Process Risk Model" developed by Erikson [11] set the target function of cost for the owner first, and then calculates possible total cost according to theory of effect, which is then used to select most economical method of risk-sharing. However, this model is limited to the fact that contractor's attitude of risk needs to be more conservative than the owner. In addition, the greatest defect is to assume that comprehension from owner and contractor on probability of particular risk and possible damage is consistent, which is not so in reality.

(3) The conceptual model of risk allocation built by Levitt and Ashley [19] is based on comprehension from owner and contractor towards risks, preference of risk acceptance and different cost needed on risk bearing. The foundation of theoretical analysis adopted by the model is based on the utility function of owner and contractor to discuss relationships of variation between different method of risk-sharing and contract amount, which acts as reference for adjusting requirement of risk-sharing contract.

Summary on result: The degree of reaction on price comparison of risk-sharing is determined by attitude from both parties of the contract towards the risk, as well as utility of monetary value, perception on risk and cost required for risk handling.

2. However, establishment of public construction needs to "administrate according to law" in everything, thus the authority in fact cannot determine personal subjective attitude on risk and utility of monetary value while making a risk-sharing decision. In addition, the authority pursues different target and benefit from construction comparing to the supplier, the perception on risk differs naturally. Therefore, the assessment on risk-sharing cost can only be discussed objectively on items that spend lower cost on risk handling or, alternatively, based on different method (or program) of risk-sharing for specific risk and calculate cost of risk for both parties to share, which takes minimization of total cost as the target and assess for optimal program of risk-sharing. The initial construction of target function is as follows:

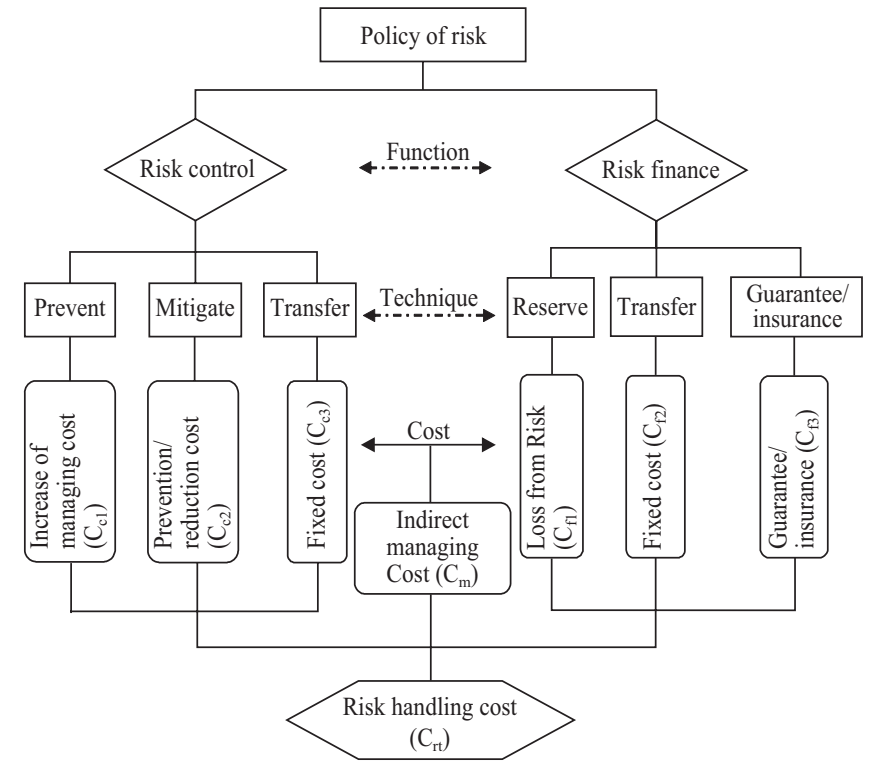

Fig. 3. Illustration on cost structure of risk handling.

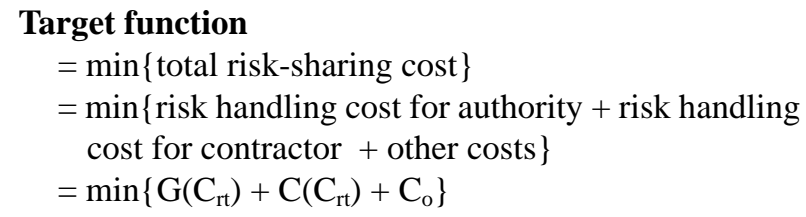

(II) Cost of Assessment

1. Risk handling $\operatorname{cost}\left(\mathrm{C}_{\mathrm{rt}}\right)$ includes cost from risk control $\left(\mathrm{C}_{\mathrm{c}}\right)$, cost from risk finance $\left(\mathrm{C}_{\mathrm{f}}\right)$ and charge on intermediate management $\left(\mathrm{C}_{\mathrm{m}}\right)$; the cost structure is detailed per Fig. 3 .

2. Other $\cos t\left(\mathrm{C}_{\mathrm{o}}\right)$ includes cost from possible transaction $\left(\mathrm{C}_{\mathrm{o} 1}\right)$, cost from dispute handling $\left(\mathrm{C}_{\mathrm{o} 2}\right)$ and other hidden $\cos \mathrm{t}\left(\mathrm{C}_{\mathrm{o} 3}\right)$.

\section{4) Evaluation Model for Risk-Sharing Performance}

(I) Evaluation Model

1. In the past, the Construction Industry Institute [4] has interviewed experts and utilized analysis with influence Figure against four clauses, namely the "Indemnity", "Consequential Damage", "Differing Conditions" and "Delay" in construction contract. Discussion has been made on influence from different rules of risk-sharing towards "Project Performance", "Working Relationship" and "Cost Effectiveness" that can be possibly obtained. Suggestion for selecting each contract clause is proposed, but it is only limited to qualitative analysis.

2. The evaluation model for contract risk-sharing performance (as per Fig. 4 below) established in this article refers to the evaluation model for performance developed by Hsieh and Wang [13] Analytic Hierarchy Process (AHP) is applied and combined with Fuzzy Synthetic Decision Method (FSDM), which specifies possible benefit of procurement contract against different risk sharing and executes quantitative analysis and evaluation. The steps are as follows: 


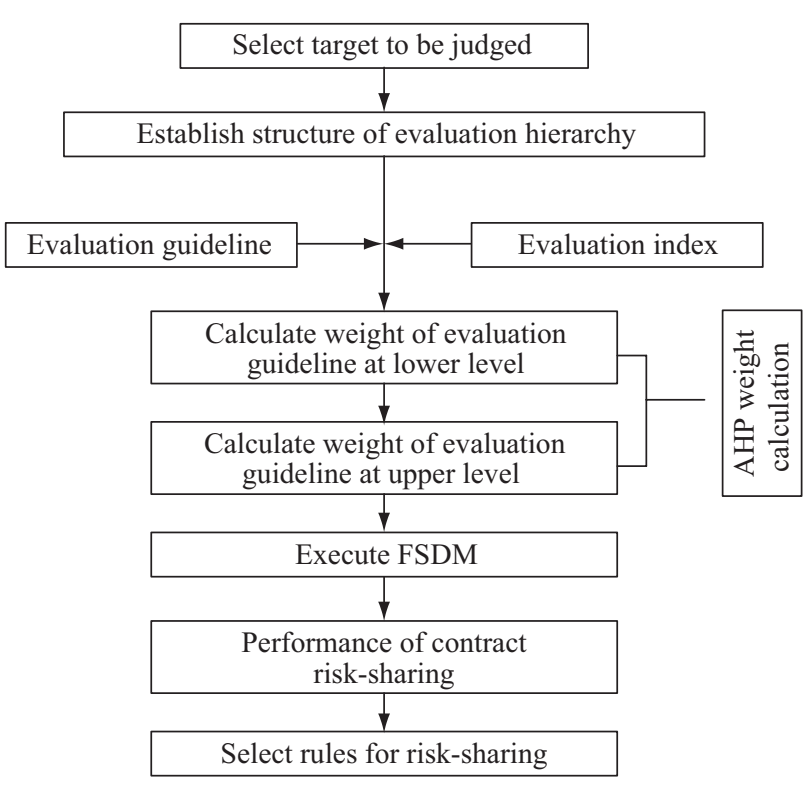

Fig. 4. Evaluation model of contract risk-sharing performance.

\section{(II) Evaluation Steps}

Step 1: Establish structure of evaluation hierarchy for risksharing performance (as per Fig. 5):

1. Benefit of construction tender invitation - A fair and reasonable risk-sharing can attract well-established suppliers to participate in tendering and enhance fair competition, which also prevent the vendor from reflecting excessive risk fund in tender price, so that acquisition of more reasonable tender price is made. Therefore, the "Benefit of construction tender invitation" will take "enhancement of virtuous tender competition" and "acquisition of reasonable tender price" as further guidelines for evaluation.

2. Result of contract cooperation - In addition to passively disarm hostile attitude between both parties of the contract, adoption of fair contract and reasonable sharing of risk can actively promote for peaceful execution of construction during work periods and reduce occurrence of contractual dispute. Therefore, the "Result of contract cooperation" will take "improvement of work relations" and "reduction of contractual dispute" as further guidelines for evaluation.

3. Performance of work execution - The final goal of construction management is to complete the work as "scheduled, formulated and specified". Similarly, a fair and reasonable risk sharing is also expected to provide positive assistance on work progress, construction quality and cost. Therefore, the "Performance of work execution" will take "promotion for work progress", "enhancement for work quality" and "reduction of construction cost" as further guidelines for evaluation.

\section{Step 2: Weight analysis of evaluation index (guideline)}

With questionnaire of AHP [17], a group of experts consisting the authority (14 members) and construction suppliers

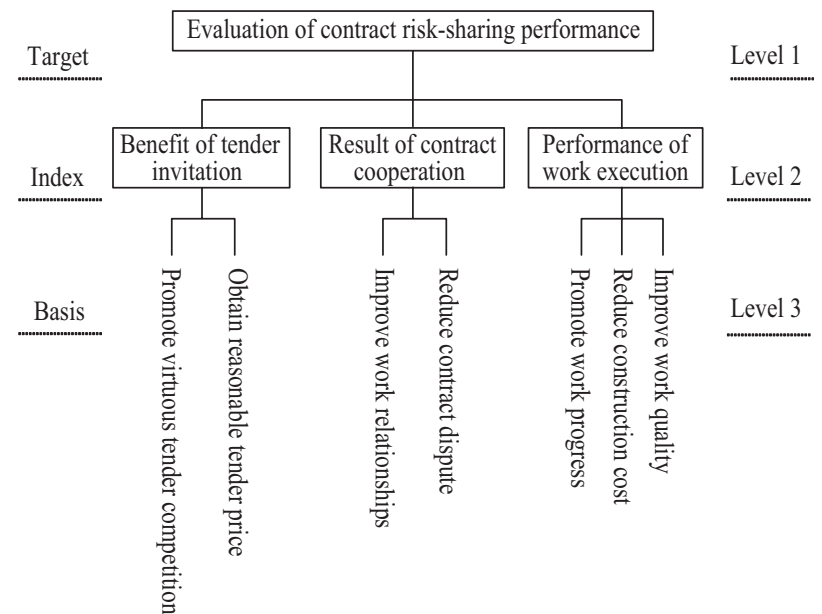

Fig. 5. Structure of evaluation hierarchy for contract risk-sharing performance.

(9 members) is consulted to first execute pair-wise comparison on three evaluation indexes, namely the "Benefit of tender invitation", "Result of contract cooperation" and "Performance of work execution". After relative weights are obtained, separate execution is made for pair-wise comparison, weight calculation and consistency assessment of each evaluation guideline [12] (results are detailed in Tables 1 and 2).

\section{Step 3: FSDM of risk-sharing performance}

With application of FSDM [23], rating of each evaluation index (guideline) is made against particular risk, where evaluation and ranking of contractual benefit for different risk-sharing alternatives are made. The steps of judgment are as follows [9, 19]:

1. Select target to be judged and establish target set of judgment: $X=\left\{x_{1}, x_{2}, \ldots, x_{i}\right\}$.

2. Determine level of judgment: $V=\left\{v_{1}, v_{2}, \ldots, v_{k}\right\}$. The fuzzy linguistic variables adopted by this article in the questionnaire [17] differs according to characteristics of each evaluation guideline $U=\left\{u_{1}, u_{2}, \ldots, u_{j}\right\}$; however, the level of judgment is divided into five levels: i.e. very high, high, medium, low, very low and this is the third type (as per Fig. 6) of eight converting scale of fuzzy linguistics recommended by Chen and Hwang [6].

3. Establish judgment matrix: $R \in X \times U, r_{i j}=R\left(x_{i}, u_{j}\right) . \quad r_{i j}$ is the superficial value of judgment target $x_{i}$ on evaluation factor (index) $u_{j}$.

$$
R x_{i}=\left(r_{j k}\right)_{n \times m}=\left[\begin{array}{cccc}
v_{1} & v_{2} & \ldots & v_{m} \\
r_{11} & r_{12} & \ldots & r_{1 m} \\
r_{21} & r_{22} & \ldots & r_{2 m} \\
: & : & : & : \\
r_{n 1} & r_{n 2} & \ldots & r_{n m}
\end{array}\right] u_{1}
$$

$R x_{i}:$ FSDM matrix of judgment target $\left(x_{i}\right)$ 
Table 1. Assessment result of AHP weight calculation.

\begin{tabular}{|c|c|c|c|c|c|c|c|c|c|c|c|}
\hline \multirow[b]{2}{*}{ 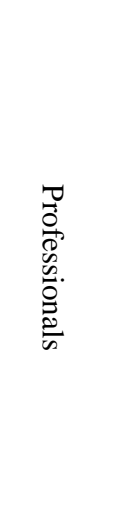 } & \multicolumn{7}{|c|}{ Relative weight of each evaluation guideline } & \multicolumn{4}{|c|}{ Hierarchial consistency assessment } \\
\hline & 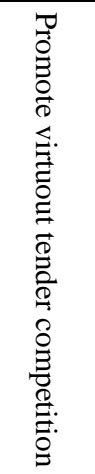 & 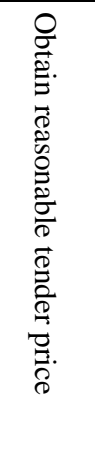 & 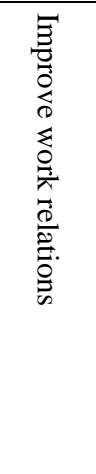 & 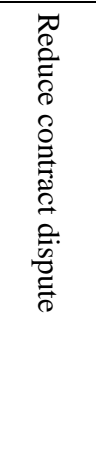 & 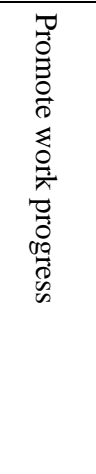 & 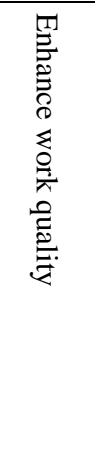 & 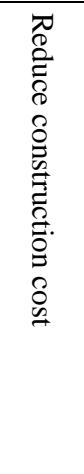 & $\mathrm{CIH} /$ & $\mathrm{RIH}=$ & $\mathrm{CRH}$ & $<0.1$ \\
\hline O01 & 0.296 & 0.037 & 0.250 & 0.084 & 0.106 & 0.153 & 0.074 & 0.038 & 0.773 & 0.049 & OK \\
\hline 02 & 0.070 & 0.139 & 0.093 & 0.458 & 0.120 & 0.060 & 0.060 & 0.130 & 0.719 & 0.018 & OK \\
\hline 03 & 0.125 & 0.500 & 0.080 & 0.159 & 0.027 & 0.027 & 0.082 & 0.005 & 0.659 & 0.008 & OK \\
\hline 04 & 0.222 & 0.222 & 0.194 & 0.193 & 0.065 & 0.075 & 0.029 & 0.010 & 0.678 & 0.015 & OK \\
\hline 05 & 0.148 & 0.295 & 0.085 & 0.185 & 0.155 & 0.077 & 0.155 & 0.006 & 0.804 & 0.011 & $\mathrm{OK}$ \\
\hline 06 & 0.549 & 0.109 & 0.130 & 0.026 & 0.037 & 0.037 & 0.112 & 0.015 & 0.688 & 0.022 & OK \\
\hline 07 & 0.198 & 0.099 & 0.082 & 0.082 & 0.089 & 0.292 & 0.158 & 0.004 & 0.893 & 0.004 & OK \\
\hline 08 & 0.227 & 0.056 & 0.070 & 0.07 & 0.283 & 0.142 & 0.142 & 0.000 & 0.908 & 0.000 & OK \\
\hline 09 & 0.167 & 0.167 & 0.167 & 0.167 & 0.133 & 0.133 & 0.066 & 0.015 & 0.773 & 0.019 & OK \\
\hline 10 & 0.215 & 0.215 & 0.024 & 0.119 & 0.122 & 0.061 & 0.244 & 0.000 & 0.829 & 0.000 & $\mathrm{OK}$ \\
\hline 11 & 0.167 & 0.167 & 0.250 & 0.083 & 0.148 & 0.129 & 0.056 & 0.018 & 0.773 & 0.023 & OK \\
\hline 12 & 0.517 & 0.172 & 0.038 & 0.113 & 0.032 & 0.096 & 0.032 & 0.003 & 0.673 & 0.004 & OK \\
\hline 13 & 0.055 & 0.055 & 0.103 & 0.206 & 0.116 & 0.349 & 0.116 & 0.001 & 0.918 & 0.001 & OK \\
\hline 14 & 0.111 & 0.222 & 0.111 & 0.222 & 0.084 & 0.167 & 0.083 & 0.015 & 0.773 & 0.019 & OK \\
\hline $\mathrm{C} 01$ & 0.200 & 0.400 & 0.150 & 0.050 & 0.080 & 0.040 & 0.080 & 0.000 & 0.696 & 0.000 & OK \\
\hline 02 & 0.099 & 0.197 & 0.082 & 0.082 & 0.216 & 0.108 & 0.216 & 0.003 & 0.893 & 0.003 & OK \\
\hline 03 & 0.072 & 0.213 & 0.072 & 0.072 & 0.137 & 0.121 & 0.313 & 0.005 & 0.909 & 0.006 & OK \\
\hline 04 & 0.450 & 0.150 & 0.050 & 0.150 & 0.108 & 0.033 & 0.059 & 0.001 & 0.696 & 0.001 & OK \\
\hline 05 & 0.095 & 0.047 & 0.285 & 0.285 & 0.096 & 0.096 & 0.096 & 0.004 & 0.746 & 0.005 & OK \\
\hline 06 & 0.083 & 0.167 & 0.333 & 0.167 & 0.062 & 0.126 & 0.062 & 0.000 & 0.725 & 0.000 & OK \\
\hline 07 & 0.070 & 0.070 & 0.213 & 0.070 & 0.189 & 0.189 & 0.189 & 0.009 & 0.909 & 0.010 & OK \\
\hline 08 & 0.055 & 0.055 & 0.038 & 0.305 & 0.109 & 0.219 & 0.219 & 0.013 & 0.898 & 0.014 & OK \\
\hline 09 & 0.200 & 0.200 & 0.133 & 0.067 & 0.133 & 0.133 & 0.134 & 0.006 & 0.812 & 0.007 & OK \\
\hline$\sum_{i=1}^{n} X_{i} / n$ & 0.191 & 0.172 & 0.132 & 0.144 & 0.115 & 0.124 & 0.122 & & & & \\
\hline
\end{tabular}

$r_{j k}$ : Degree of membership for judgment target $\left(x_{i}\right)$ judged as level $\left(v_{k}\right)$ according to evaluation guideline $\left(u_{j}\right)$ (number of experts judged as level $v_{k}$ /total number of experts interviewed)

\section{Conversion of fuzzy performance}

According to calculation result from Chen and Hwang [6], the membership values represented by each fuzzy linguistics are: $u_{t(\text { very high })}=0.909, u_{t(\text { high })}=0.717, u_{t(\text { medium })}=0.500, u_{t(\text { low })}=$ $0.283, u_{t \text { (very low })}=0.091$. The following section will base on these membership values and convert each fuzzy judgment set into precise performance value.

(1) Apply the following formulae for fuzzy performance conversion of each judgment matrix.
$P_{i j}=\sum_{k=1}^{m} r_{j k} \times u_{t}\left(v_{k}\right),(j=1,2, \ldots . n ; k=1,2, \ldots . m)$

$P_{i j}$ : Fuzzy performance value for judgment target $\left(x_{i}\right)$ above evaluation guideline $\left(u_{j}\right)$.

$r_{j k}$ : Degree of membership for judgment target $\left(x_{i}\right)$ judged as level $\left(v_{k}\right)$ according to evaluation guideline $\left(u_{j}\right)$ (number of experts judged as level $v_{k}$ /total number of experts interviewed)

$u_{t}\left(v_{k}\right)$ : Fuzzy linguistic membership value at level $v_{k}$.

(2) Regarding the performance evaluation on possibility of "obtaining reasonable tender price", separate calculation is made for fuzzy performance value from construction 
Table 2. Relative weight of evaluation index and guideline for contract risk-sharing performance.

\begin{tabular}{|l|l|l|c|}
\hline Evaluation index & Weight & Evaluation guideline & Weight \\
\hline \multirow{2}{*}{$\begin{array}{l}\text { Benefit of } \\
\text { tender } \\
\text { invitation }\end{array}$} & \multirow{2}{*}{0.363} & $\begin{array}{l}\text { Promote virtuous } \\
\text { tender competition }\end{array}$ & 0.191 \\
\cline { 3 - 4 } & & $\begin{array}{l}\text { Reduce contract } \\
\text { dispute }\end{array}$ & 0.172 \\
\hline \multirow{2}{*}{$\begin{array}{l}\text { Result of } \\
\text { contract } \\
\text { cooperation }\end{array}$} & \multirow{2}{*}{0.276} & $\begin{array}{l}\text { Improve work } \\
\text { relations }\end{array}$ & 0.132 \\
\cline { 3 - 4 } & & $\begin{array}{l}\text { Reduce contract } \\
\text { dispute }\end{array}$ & 0.144 \\
\hline \multirow{2}{*}{$\begin{array}{l}\text { Performance of } \\
\text { construction } \\
\text { execution }\end{array}$} & \multirow{2}{*}{0.361} & $\begin{array}{l}\text { Promote work } \\
\text { progress }\end{array}$ & 0.115 \\
\cline { 3 - 4 } & $\begin{array}{l}\text { Enhance work } \\
\text { quality }\end{array}$ & 0.124 \\
\cline { 3 - 4 } & & $\begin{array}{l}\text { Reduce construction } \\
\text { cost }\end{array}$ & 0.122 \\
\hline
\end{tabular}

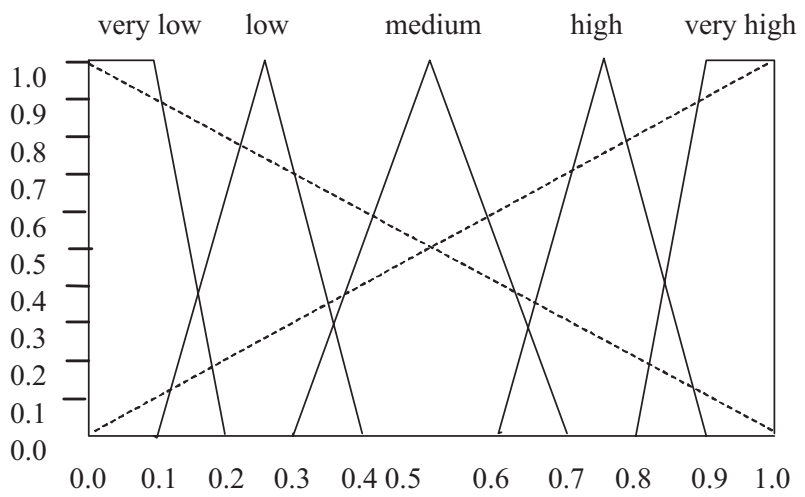

Fig. 6. Converting scale of fuzzy linguistics.

supplier's tender price reaction and budgeted bottom price that might be allocated by the owner. After that, the ratio of fuzzy performance is allocated into five levels, and the membership value $\left.\mu_{t}\left(r_{t / \mathrm{b}}\right)\right)$ of level belonged is taken as fuzzy performance value for possibility of "obtaining reasonable tender price".

$\mathrm{r} t / \mathrm{b}=\frac{\text { reaction of tender price from construction vendors (fuzzy performance value) }}{}$ owner's budgeted bottom price (fuzzy performance value)

when $r t / b<0.8$, the assessment is "excellent"

when $0.8 \leq r t / b<0.9$, the assessment is "good"

when $0.9 \leq r t / b \leq 1.1$, the assessment is "okay"

when $1.1<r t / b \leq 1.2$, the assessment is "bad"

when $1.2<r t / b$, the assessment is "worst"

5. The calculation of synthetic judgment $E\left(x_{i}\right)$ for each judgment target $x_{i}$ select the best option according to maximum degree of membership.

$$
\left[\begin{array}{c}
E\left(X_{1}\right) \\
E\left(X_{2}\right) \\
\vdots \\
E\left(X_{i}\right)
\end{array}\right]=\left[\begin{array}{cccc}
P_{11} & P_{12} & \cdots & P_{1 n} \\
P_{21} & P_{22} & \cdots & P_{2 n} \\
\vdots & \vdots & \vdots & \vdots \\
P_{m 1} & P_{m 2} & \cdots & P_{m n}
\end{array}\right]_{i \times j} \cdot\left[\begin{array}{c}
w_{1} \\
w_{2} \\
\vdots \\
w_{j}
\end{array}\right]_{j \times 1}
$$

\section{Setting of Risk-Sharing Program}

Suitable decision model of sharing is selected against characteristics of each contract risk and sharing program of each contract risk is set according to result of decision analysis, which includes: scope of risk that shall be shared by both parties, basis of sharing and method of sharing.

The authority can consider the characteristics of project construction, goal of planning, competitiveness and demand-supply environment in the market, as well as financial budget and managing ability of the authority itself for selection of adequate risk reduction and/or measure of financial benefit. This can reduce probability of risk occurrence, loss and financial (or risk) burden on the contractor, which further improves supplier's ability for contract performance and promote for smooth progress of construction.

\section{Structure of Risk-Sharing Decision System}

Following the steps of decision analysis above, this article has compiled factors of decision consideration at each phase for constructing the structure of decision system for public construction contract risk-sharing (as per Fig. 7), which provides foundation of selecting risk-sharing decision for the authority.

\section{APPLICATION AND PRACTICAL EXAMPLES OF DECISION ANALYSIS ON RISK-SHARING}

\section{Investigation and Analysis on Contract Risk of Public Construction}

According to results from investigations and statistics of this article (detailed per Table. 3), the most principal contract risk of public construction in Taiwan at present include the following:

1. "Fulfillment": (1) delay in removal of public piping or above-ground objects; (2) delay in acquisition of construction land; (3) delay in work; and (4) delay in cooperation with relevant supplier (construction).

2. On the aspect of "change in external environment": (1) public resistance and interference; (2) rising price and wages; (3) natural disasters such as typhoon, earthquake and flood; as well as (4) abnormal condition on site, which induce maximum impact to the construction.

Since the "rising price and wages" induce most direct influence on work cost, it also generates the most severe possible impact; thus the contractor lists this item as the primary contract risk. Furthermore, although the amplitude of wage variation is smaller over recent years, the overall price of 


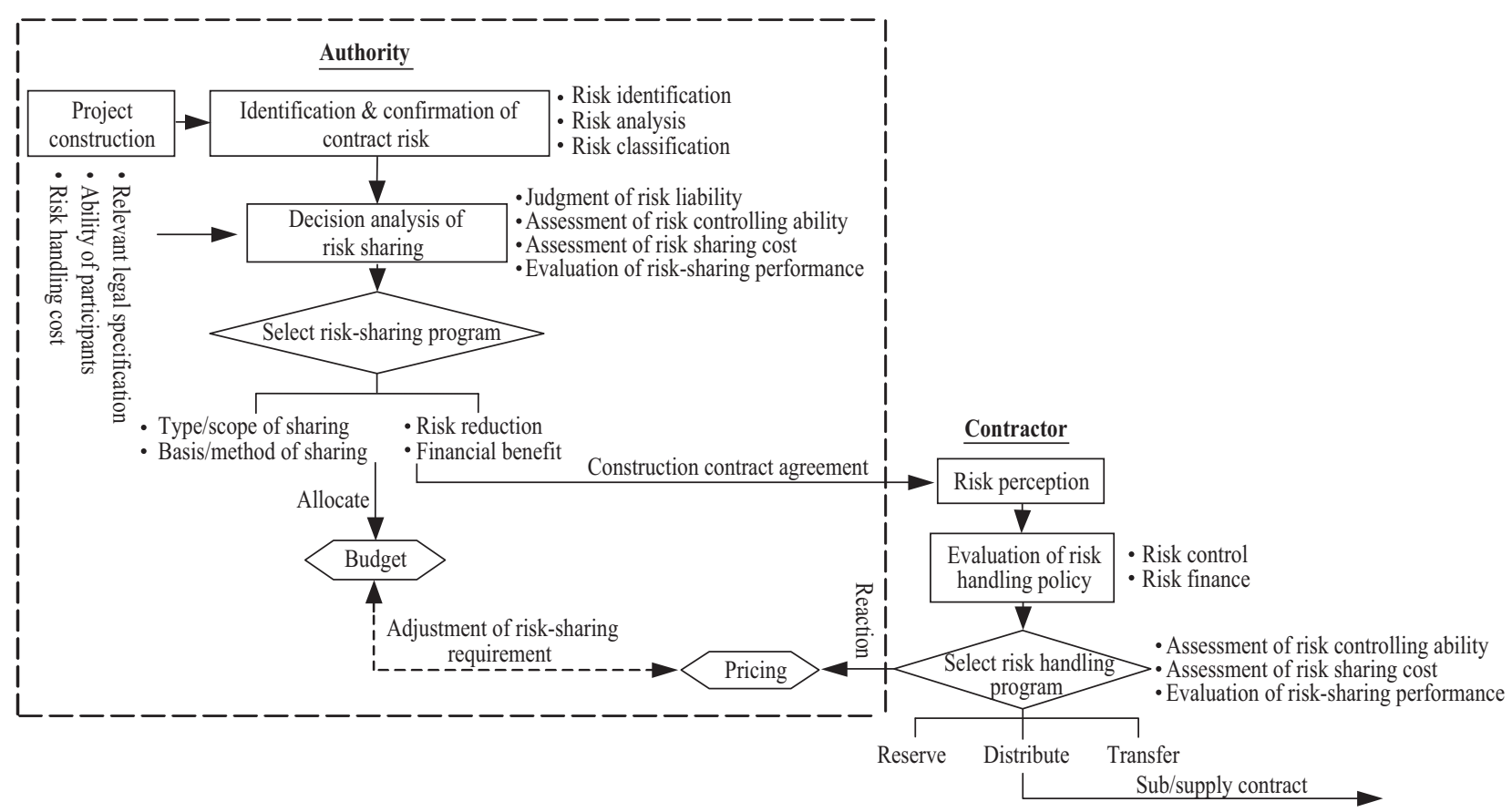

Fig. 7. Structure of public construction contract risk-sharing decision system.

construction project and concrete has raised for approximately $40 \%$; the price of aggregate and reinforcement even rise to amplitude of $80 \%$ or more than $110 \%$ (as per Fig. 8). This has caused tremendous cost burden to suppliers and several appeals have been made to the construction authority for request of setting relevant measures on compensation, which creates extensive difficulty for the authorities. In view of this, this article takes the risk from "rising price and wages" as the practical example of contract risk-sharing decision analysis.

\section{Decision Analysis of Risk-Sharing for Rising Price and Wages}

Regarding the risk-sharing for "rising price and wages" in accordance with result from investigation and statistics of this article (detailed per Table 4), approximately 44\% of experts think that risk model of "assessment on controlling ability" can be adopted and taken as foundation of sharing decision; on the other hand, $39 \%$ of experts thank that result of "evaluation on sharing performance" can be referred for synthetic judgment. Separate assessments are as follows: (I) Assessment of risk controlling ability

The results of assessment made in this article after consulting with professional opinions (detailed per Table 5):

1. Influencing ability: The rise and fall of price and wages are basically influenced by overall economy, demand-supply environment in the market, relevant regulation and policy; thus the time of rise/fall, magnitude, the authority and supplier has no direct influencing ability.

2. Controlling ability: Since the units interviewed are authorities and contractors of major constructions, they have substantial experience in handling rising/falling price and wages; in addition, each of them has certain channel for information and price enquiry, so they can control the tendency of price rise/fall and respond as soon as possible.

3. Handling ability: The authority bears lower capital cost and it is capable of adopting adequate risk-sharing measure (e.g. offer advance payment to suppliers for material preparation), which reduces risk of price fluctuation; the suppliers on other hand are more capable of distributing the risk via organized supply chain (e.g. reduce the wages when price rises and delay payment to sub-contractors) and reduce influence of price fluctuation via risk-prevention measures such as contract of long-term supply and purchase of futures.

Summing up the results from assessment above, the authority and supplier has certain risk controlling ability each, thus this risk is preferably to be shared by both parties.

\section{1) Evaluation on Risk-Sharing Performance}

As for the evaluation on risk-sharing performance, this article refers to adjustment regulated [21] by each country (detailed per Table 6 ) and takes 3 methods that are more representative. According to degree of risk undertaken by both parties of the contract, type A, B and C clause of "price adjustment" are set and taken as judgment target; moreover, the evaluation model established in this article for contract risk sharing performance is applied for executing assessment and FSDM of each evaluation guideline.

Clause A: The construction amount is adjusted in accordance with actual variation of rise/fall on overall price (the owner undertakes most or all risks). 
Table 3. Investigation and statistics of public construction contract risks.

\begin{tabular}{|c|c|c|c|c|c|c|c|c|c|}
\hline \multirow[b]{2}{*}{ Contract risk } & \multicolumn{3}{|c|}{ Construction owner } & \multicolumn{3}{|c|}{ Contractor } & \multicolumn{3}{|c|}{ Overall members } \\
\hline & 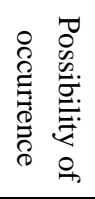 & 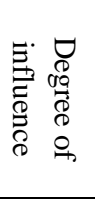 & 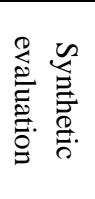 & 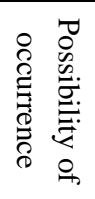 & 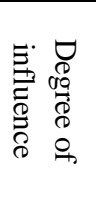 & 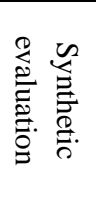 & 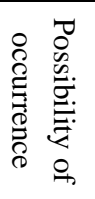 & 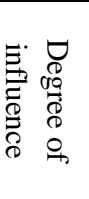 & 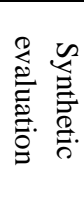 \\
\hline \multicolumn{10}{|l|}{\begin{tabular}{|l|} 
Defects in contract fulfillment \\
\end{tabular}} \\
\hline Delay in acquisition of construction land & 2.04 & 4.65 & 3 & 2.38 & 4.77 & 1 & 2.17 & 4.69 & 2 \\
\hline $\begin{array}{l}\text { Delay in removal of public piping or } \\
\text { above-ground objects }\end{array}$ & 2.43 & 4.39 & 1 & 2.46 & 4.46 & 2 & 2.44 & 4.42 & 1 \\
\hline $\begin{array}{l}\text { Delay in approval of relevant permits and } \\
\text { certificates }\end{array}$ & 1.65 & 3.83 & 5 & 1.54 & 3.85 & 8 & 1.61 & 3.83 & 6 \\
\hline Delay in supply of design drawing or equipments & 1.27 & 3.50 & 10 & 1.31 & 3.77 & 10 & 1.29 & 3.60 & 10 \\
\hline $\begin{array}{l}\text { Delay in work instruction and administration of } \\
\text { contract }\end{array}$ & 1.52 & 3.39 & 9 & 1.85 & 3.77 & 6 & 1.64 & 3.53 & 8 \\
\hline $\begin{array}{l}\text { Delay in cooperation with relevant supplier } \\
\text { (construction) }\end{array}$ & 2.09 & 3.73 & 4 & 2.00 & 3.92 & 4 & 2.06 & 3.80 & 4 \\
\hline Delay in work & 2.36 & 4.18 & 2 & 2.46 & 4.15 & 3 & 2.40 & 4.17 & 3 \\
\hline Mistake in work & 1.50 & 4.18 & 6 & 1.77 & 4.31 & 5 & 1.60 & 4.21 & 5 \\
\hline Accident under work safety & 1.45 & 3.91 & 7 & 1.77 & 3.69 & 7 & 1.57 & 3.83 & 7 \\
\hline Traffic and environment contamination & 1.48 & 3.62 & 8 & 1.92 & 3.08 & 8 & 1.65 & 3.41 & 9 \\
\hline \multicolumn{10}{|l|}{ Variation of external environment } \\
\hline $\begin{array}{l}\text { Natural disasters such as land slide, earthquake, } \\
\text { flood and typhoon }\end{array}$ & 1.65 & 3.91 & 3 & 2.00 & 3.54 & 3 & 1.78 & 3.78 & 3 \\
\hline War, riot or nuclear incidence & 1.00 & 4.40 & 6 & 1.08 & 4.33 & 6 & 1.03 & 4.38 & 6 \\
\hline Abnormal condition on site & 1.59 & 4.00 & 4 & 1.38 & 4.08 & 5 & 1.51 & 4.03 & 4 \\
\hline Amendment of relevant regulation and policy & 1.52 & 3.91 & 5 & 1.67 & 3.75 & 4 & 1.57 & 3.86 & 5 \\
\hline Public resistance and interference & 2.00 & 4.26 & 1 & 1.92 & 4.23 & 2 & 1.97 & 4.25 & 1 \\
\hline Rising price and wages & 1.86 & 4.13 & 2 & 2.21 & 4.26 & 1 & 1.98 & 4.19 & 2 \\
\hline Variation of tax rate & 1.20 & 2.95 & 8 & 1.31 & 2.85 & 8 & 1.24 & 2.91 & 8 \\
\hline Variation of exchange and tax rate & 1.45 & 2.85 & 7 & 1.54 & 2.92 & 7 & 1.48 & 2.88 & 7 \\
\hline
\end{tabular}

*Possibility of occurrence: large $=3$, medium $=2$, small $=1$

Degree of influence: very important $=5$, important $=4$, normal $=3$, minor $=2$, irrelevant $=1$

Synthetic evaluation: ranked according to magnitude of product from "Possibility of occurrence" and "Degree of influence".

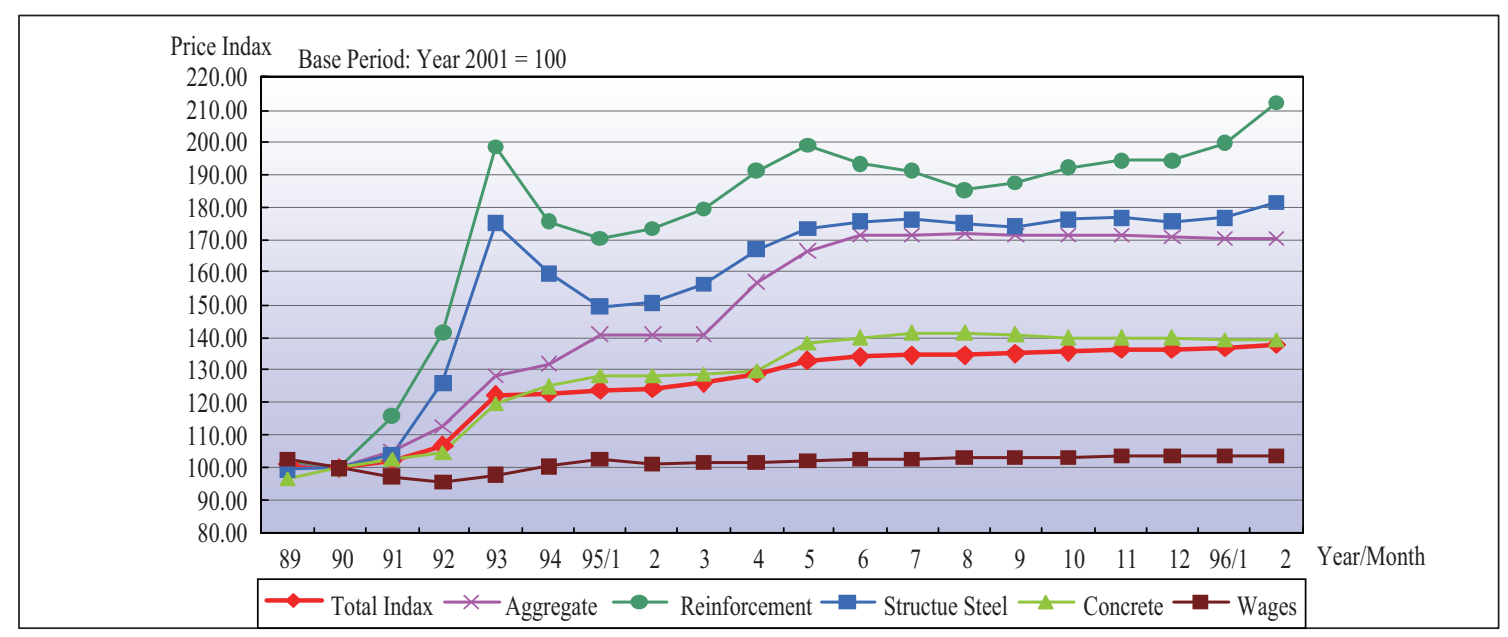

Fig. 8. Historical curve of variation on project price and wages. 
Table 4. Investigation and statistics of applicable sharing decision model for contract risks.

\begin{tabular}{|c|c|c|c|c|c|}
\hline \multirow[b]{2}{*}{ Contract risk } & \multirow[b]{2}{*}{ Characteristics } & \multicolumn{4}{|c|}{$\begin{array}{c}\text { Decision model for risk-sharing } \\
\text { (multiple selection allowed) }\end{array}$} \\
\hline & & 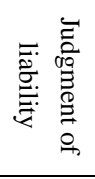 & 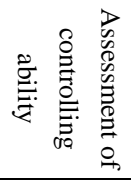 & 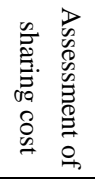 & 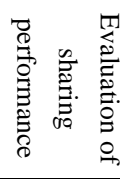 \\
\hline \multicolumn{6}{|l|}{ Defects in contract fulfillment } \\
\hline Delay in acquisition of construction land & & 59.3 & 27.1 & 5.1 & 10.2 \\
\hline Delay in removal of public piping or above-ground objects & & 32.2 & 44.1 & 15.3 & 10.2 \\
\hline Delay in approval of relevant permits and certificates & & 27.1 & 44.1 & 15.3 & 13.5 \\
\hline Delay in supply of design drawing or equipments & & 39.0 & 47.4 & 5.1 & 8.5 \\
\hline Delay in work instruction and administration of contract & & 61.0 & 32.2 & 5.1 & 8.5 \\
\hline Delay in cooperation with relevant supplier (construction) & & 52.5 & 27.1 & 13.5 & 18.6 \\
\hline Delay in work & & 69.5 & 22.0 & 8.5 & 8.5 \\
\hline Mistake in work & & 69.5 & 22.0 & 11.9 & 8.5 \\
\hline Accident under work safety & & 66.1 & 22.0 & 18.6 & 8.5 \\
\hline Traffic and environment contamination & & 57.6 & 22.0 & 22.0 & 13.5 \\
\hline \multicolumn{6}{|l|}{ Variation of external environment } \\
\hline Natural disasters such as land slide, earthquake, flood and typhoon & & 3.4 & 39.0 & 39.0 & 37.3 \\
\hline War, riot or nuclear incidence & & 3.4 & 37.3 & 33.9 & 33.9 \\
\hline Abnormal condition on site & & 25.4 & 50.8 & 25.4 & 20.3 \\
\hline Amendment of relevant regulation and policy & & 32.2 & 37.3 & 18.6 & 25.4 \\
\hline Public resistance and interference & & 18.6 & 44.1 & 25.4 & 27.1 \\
\hline Rising price and wages & & 6.8 & 44.1 & 25.4 & 39.0 \\
\hline Variation of tax rate & & 11.9 & 42.4 & 15.3 & 37.3 \\
\hline Variation of exchange and tax rate & & 11.9 & 42.4 & 22.0 & 39.0 \\
\hline
\end{tabular}

*The values listed are in percentages $(\%)$

Table 5. Result from assessment on risk controlling ability on rising price and wages.

\begin{tabular}{|c|c|c|c|c|c|c|c|c|c|c|c|c|c|c|c|}
\hline \multirow{3}{*}{ Item assessed } & \multirow{2}{*}{\multicolumn{2}{|c|}{$\begin{array}{c}\begin{array}{c}\text { Influencing } \\
\text { ability }\end{array} \\
\begin{array}{c}\text { Degree of } \\
\text { participation }\end{array}\end{array}$}} & \multicolumn{4}{|c|}{ Controlling ability } & \multicolumn{6}{|c|}{ Handling ability } & \multirow{2}{*}{\multicolumn{3}{|c|}{ Risk distribution }} \\
\hline & & & \multicolumn{2}{|c|}{$\begin{array}{c}\text { Relevant } \\
\text { experience }\end{array}$} & \multicolumn{2}{|c|}{$\begin{array}{c}\text { Information } \\
\text { channel }\end{array}$} & \multicolumn{2}{|c|}{ Organization } & \multicolumn{2}{|c|}{$\begin{array}{l}\text { Resources } \\
\text { possessed }\end{array}$} & \multicolumn{2}{|c|}{$\begin{array}{c}\text { Professional } \\
\text { technique }\end{array}$} & & & \\
\hline & 密 & $\frac{\mathscr{E}}{\frac{\tilde{D}}{9}}$ & 蔦 & $\frac{\mathscr{E}}{\frac{\tilde{D}}{0}}$ & 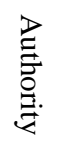 & $\frac{\mathscr{E}}{\frac{E}{0}}$ & 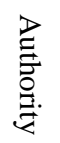 & $\frac{\mathscr{E}}{\tilde{D}}$ & 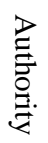 & $\frac{\mathscr{E}}{\stackrel{E}{0}}$ & 蔦 & $\frac{\mathscr{E}}{\stackrel{0}{\frac{D}{9}}}$ & 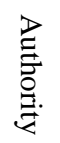 & $\begin{array}{l}\mathscr{\mathscr { 2 }} \\
\stackrel{0}{0}\end{array}$ & $\frac{\mathscr{E}}{\frac{E}{0}}$ \\
\hline $\begin{array}{c}\text { Result from } \\
\text { assessment }\end{array}$ & & & D & $\bigcirc$ & $\bigcirc$ & $\bigcirc$ & & (C) & (a) & & $\bigcirc$ & O & & $\sqrt{ }$ & \\
\hline
\end{tabular}

*Risk controlling ability: ( $)$ : with relative advantage $\bigcirc$ : equivalent

Clause B: The adjustment is only made when portion of overall price rise/fall that has exceeded $5 \%$ (both parties share the risk).

Clause C: No adjustment is made despite of rise/fall on price and wages (the contractor undertakes most or all risks).

1. On the aspect of "promoting virtuous tender competition": all experts think that Clause A or B impose positive assistance for promoting virtuous competition of construction tenders (differs slightly in extent), where Clause $\mathrm{C}$ may possibly generate negative influence.

2. According to fuzzy performance ration from supplier's "reaction on tender price" and owner's possible "budgeted bottom price," the ranking for reasonable tender price that can possibly be obtained by 3 clauses above is as follows:

$$
\text { Clause A with } \begin{aligned}
r_{t / b} & =0.091 / 0.091 \\
& =1.000 \text { is ranked as "okay" }
\end{aligned}
$$


Table 6. Summary of adjustment for variation of price and wages in each country.

\begin{tabular}{|c|c|}
\hline Country & Adjustment \\
\hline FIDIC & $\begin{array}{l}\text { (1) For construction that has duration less than } 1 \text { year and fixed price, the construction payment is not to be adjusted; } \\
\text { (2) Adjustment is calculated from difference between basic price and actual price for local manpower and particular } \\
\text { material; or } \\
\text { (3) Certain formula is applied according to particular price index for calculating the adjustment for portion of actual rise. }\end{array}$ \\
\hline UK & In accordance with FIDIC's adjustment. \\
\hline Germany & Adjust according to different in actual price. \\
\hline Austria & $\begin{array}{l}\text { (1) Simplification: The construction price is divided into total wages and total material, which is adjusted separately } \\
\text { according to published index. } \\
\text { (2) Precision: The adjustment is made according to weighted average price of main material and wages. }\end{array}$ \\
\hline USA & Coordination is made between the owner and contractor per cases. \\
\hline Japan & $\begin{array}{l}\text { (1) The construction contract is not to be adjusted within } 1 \text { year since the date of signature. } \\
\text { (2) After } 1 \text { year, adjustment is made for portion of price index (or particular information) that rises over } 1.5 \% \text {. } \\
\text { (3) When there is obvious change on price of main material or inflation, adjustment is made from coordination between two } \\
\text { parties. }\end{array}$ \\
\hline Singapore & $\begin{array}{l}\text { (1) The contract prices exceeds NT\$ } 1 \text { million. } \\
\text { (2) Adjust according to difference in actual price: the government undertakes } 70 \% \text { and the contractor undertakes } 30 \% \text {. }\end{array}$ \\
\hline Taiwan & $\begin{array}{l}\text { Construction payment is not adjusted according to price fluctuation; or } \\
\text { (1) Items that are construction and repair works and with duration of more than } 1 \text { year. } \\
\text { (2) For particular price index published by Directorate-General of Budget, Accounting and Statistics, Executive Yuan with } \\
\text { portion of rising/falling amplitude that exceeds } 5 \% \text {, the construction payment (or the payment of particular items } \\
\text { specified by the authority during tender invitation) is adjusted after completion of inspection. }\end{array}$ \\
\hline
\end{tabular}

$$
\begin{aligned}
\text { Clause B with } r_{t / b} & =0.451 / 0.457 \\
& =0.987 \text { is ranked as "okay" } \\
\text { Clause C with } r_{t / b} & =0.822 / 0.681 \\
& =1.207 \text { is ranked as "worst" }
\end{aligned}
$$

3. As for influence of "relationships in contract work" on both Party A and B, both the owner and supplier think that Clause A or B imposes low and positive influence on work harmony, while Clause $\mathrm{C}$ may possibly imposes low and negative influence.

4. There are approximately $90 \%$ of experts think that chances of possible contract dispute from adoption of Clause A or B are very low. For adoption of Clause $\mathrm{C}$ on the other hand, there are approximately $50 \%$ in each group of owner and suppliers think that the chances of contract dispute are very high, if the price fluctuation exceeds bearable scope of the contractor.

5. As for the influence of "work execution performance":

(1) The viewpoints between owner and supplier on influence from Clause A and B against execution performance of work duration and cost are rather different. The reason mainly arises from the fact that some owners worry about supplier's possible and intentional extension of work duration for extra compensation from price adjustment; hence the negative viewpoint. Most suppliers think that they can be better off the worries and concentrate on actual work if there is adequate measure of price adjustment; hence the positive attitude.
(2) Yet for influence from Clause $\mathrm{C}$ towards work execution performance, most of both parties hold the negative viewpoint except for minor difference on the extent.

$$
E=P \cdot W
$$

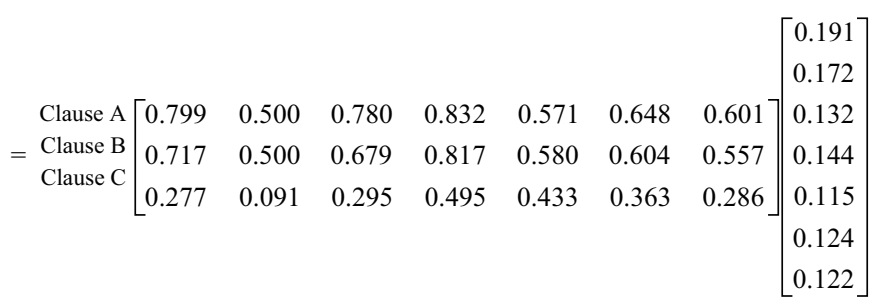

$=\left[\begin{array}{l}0.680 \\ 0.640 \\ 0.308\end{array}\right] \div 1.628=\left[\begin{array}{l}0.418 \\ 0.393 \\ 0.189\end{array}\right]$

6. FSDM: After summarizing the result of synthetic assessment made by experts towards 3 different clauses of risksharing above (detailed per Table 7), as well as conversion of fuzzy performance, weighted calculation and unified process (calculation results shown as follows), the FSDM index for Clause A, B and C is [0.418, 0.393, 0.189] respectively. This reveals that the regulation of "price adjustment" shall adopt Clause A (adjust according to actual rise/fall) preferably, which is also the clause adopted by more advanced countries in Europe and America at present. However, there is not much difference in fuzzy synthetic performance value obtained from Clause B (only adjust the portion with rise/fall exceeding $5 \%$ ). 
Table 7. Synthetic assessment from experts on different regulation of risk-sharing on "price adjustment".

Clause A

\begin{tabular}{|c|c|c|c|c|c|c|}
\hline $\begin{array}{l}\text { Judgment level } \\
\text { Evaluation Guideline }\end{array}$ & Very high & High & Medium & Low & Very low & $\begin{array}{l}\text { Fuzzy } \\
\text { performance } \\
\text { value }\end{array}$ \\
\hline Enhance virtuous competition & 0.566 & 0.304 & 0.130 & 0.000 & 0.000 & 0.799 \\
\hline Obtain reasonable tender price & \multicolumn{5}{|c|}{$\mathrm{r}_{\mathrm{t} / \mathrm{b}}=0.091 / 0.091=1.000$} & 0.500 \\
\hline Improve work relationships & 0.566 & 0.261 & 0.130 & 0.043 & 0.000 & 0.500 \\
\hline Reduce contract dispute & 0.740 & 0.174 & 0.043 & 0.043 & 0.000 & 0.832 \\
\hline Promote work progress & 0.217 & 0.174 & 0.392 & 0.174 & 0.043 & 0.571 \\
\hline Enhance work quality & 0.174 & 0.392 & 0.391 & 0.043 & 0.000 & 0.648 \\
\hline Reduce construction cost & 0.217 & 0.436 & 0.043 & 0.217 & 0.087 & 0.601 \\
\hline
\end{tabular}

Clause B

\begin{tabular}{|c|c|c|c|c|c|c|}
\hline $\begin{array}{l}\text { Judgment level } \\
\text { Evaluation Guideline }\end{array}$ & Very high & High & Medium & Low & Very low & $\begin{array}{c}\text { Fuzzy } \\
\text { performance } \\
\text { value } \\
\end{array}$ \\
\hline Enhance virtuous competition & 0.100 & 0.800 & 0.100 & 0.000 & 0.000 & 0.717 \\
\hline Obtain reasonable tender price & \multicolumn{5}{|c|}{$r_{t / b}=0.451 / 0.457=0.987$} & 0.500 \\
\hline Improve work relationships & 0.045 & 0.728 & 0.227 & 0.000 & 0.000 & 0.679 \\
\hline Reduce contract dispute & 0.609 & 0.348 & 0.000 & 0.043 & 0.000 & 0.817 \\
\hline Promote work progress & 0.000 & 0.455 & 0.454 & 0.091 & 0.000 & 0.580 \\
\hline Enhance work quality & 0.048 & 0.429 & 0.476 & 0.047 & 0.000 & 0.604 \\
\hline Reduce construction cost & 0.000 & 0.650 & 0.000 & 0.300 & 0.050 & 0.557 \\
\hline
\end{tabular}

Clause C

\begin{tabular}{|c|c|c|c|c|c|c|}
\hline $\begin{array}{l}\text { Judgment level } \\
\text { Evaluation Guideline }\end{array}$ & Very high & High & Medium & Low & Very low & $\begin{array}{c}\text { Fuzzy } \\
\text { performance } \\
\text { value } \\
\end{array}$ \\
\hline Enhance virtuous competition & 0.000 & 0.048 & 0.095 & 0.619 & 0.238 & 0.277 \\
\hline Obtain reasonable tender price & \multicolumn{5}{|c|}{$\mathrm{r}_{\mathrm{t} / \mathrm{b}}=0.822 / 0.681=1.207$} & 0.091 \\
\hline Improve work relationships & 0.000 & 0.000 & 0.277 & 0.591 & 0.182 & 0.295 \\
\hline Reduce contract dispute & 0.000 & 0.479 & 0.130 & 0.261 & 0.130 & 0.495 \\
\hline Promote work progress & 0.000 & 0.182 & 0.409 & 0.318 & 0.091 & 0.433 \\
\hline Enhance work quality & 0.000 & 0.045 & 0.364 & 0.500 & 0.091 & 0.363 \\
\hline Reduce construction cost & 0.045 & 0.045 & 0.045 & 0.592 & 0.273 & 0.286 \\
\hline
\end{tabular}

\section{2) Preliminary Discussion of Risk-Sharing Program}

Combining the assessment on risk controlling ability and evaluation result of sharing performance above, the relevant risk on "rising price and wages" is announced to be shared by both parties for encouraging the supplier to distribute risks via organizational supply chain. As for the sharing program, this article has drafted according to present regulation, requirement of foreign/domestic construction contract (detailed per Table 6) and professional opinions:

1. Methods of sharing:

(1) For construction that has duration less than (1 year), the construction payment is not to be adjusted along with price fluctuation.

(2) For construction that has duration more than (1 year), the construction payment can be adjusted according to particular price index, particularly on the portion with overall (or particular item) price rising/falling amplitude exceeding $(5 \%)$.

2. Requirement of sharing:

When the construction payment is adjusted according to particular price index, the following items shall be specified clearly in the contract:

(1) The cost items that have to be adjusted (overall or particular items).

(2) Particular price index and base period as basis for the adjustment.

(3) Situation that needs to be adjusted or not adjusted.

(4) Calculation formula for the adjustment.

(5) Adjustment data and proof that have to be provided by supplier.

(6) Management fee, insurance premium, profit and other taxes/miscellaneous fees (excluding business tax) are not to be adjusted. 
(7) Applicable measures of adjustment for design variation or overdue contract execution.

3. Measure of sharing:

The authority can consider on characteristics and budget of project construction, as well as its own resources possessed and managing ability to select the following measures of risksharing:

(1) Provide advance payment to relieve contractor's burden of fund raising at beginning of construction and reduce influence from price fluctuation. However, practical measures of supplier receiving and returning the advanced payment shall be specified clearly in the contract, where the supplier is requested to provide advanced payment bond first.

(2) The price of qualified materials is costed first to relieve supplier's financial pressure. However, supplier's substantial obligation of safe keeping shall be specified in the contract.

(3) Major equipments or materials are provided by the authority to relieve supplier's risk of material supply. However, relevant matters of cooperation and coordination shall be specified clearly in the contract, as well as enhancing the management on supplier's contract execution.

\section{CONCLUSIONS AND SUGGESTIONS}

1. By referring to relevant literature and following logic of risk-sharing decision, the "Public Construction Contract Risk-Sharing Decision System" developed and established in this article can be provided to the authority as foundation of selecting the risk-sharing decision.

2. Unless specified clearly in relevant regulations such as the Civil Code or the Government Procurement Act, the decision analysis related to contract risk sharing in principle can take assessment result on supplier's risk controlling ability as basis of risk-sharing decision.

3. The evaluation model of contract risk-sharing performance established in this article by combining AHP and FSDM can be basis for authority upon selecting quantitative analysis for optimal risk-sharing decision.

4. According to result of decision analysis made in this article for risk of "rising price and wages", it is suggested that the authority shall select the sharing program of "adjust the portion with rising/falling amplitude exceeding (5\%) according to particular price index" for construction with duration exceeding 1 year.

5. The authority is suggested to set fair and reasonable contract that regulates rights and obligations for both parties with principle of equal and mutual benefit, which is expected to be followed in the industry. However, members from each party shall establish mutual understanding on reasonable sharing of contract risks and bring out the expected function of contract with principle of maximum sincerity.

\section{REFERENCES}

1. Allensworth, W. R., Risk Transfer in Contracts: The Architects and Engineers' and Engineers' Perspective, San Antonio, pp. 12 (1996).

2. American Consulting Engineers Council and Associated General Contractors of America, Enlightened Risk Allocation: The Twenty-First Century Owner's Guide to Cost-Effectiveness, U.S.A. (1998).

3. Arbitration Association, Selected Collection of Arbitration Cases (I) (IV) and Selected Collection of Project Arbitration Cases (I) (II), Taipei, R.O.C. (1996-2003).

4. Ashley, D. B., Dunlop, J. R., and Parker, M. M., Impact of Risk Allocation and Equity in Construction Contracts, Construction Industry Institute (1989).

5. Bunni, N. G., Construction Insurance, Elsevier Applied Science Publishers, pp. 35-38 (1986).

6. Chen, S. J. and Hwang, C. L., Fuzzy Multiple Attribute Decision Making, Methods and Applications, Springer-Verlag (1992).

7. Chen, Y. S., Economic Analysis on Contract Law, Institute of Law, National Taiwan University, Taipei, R.O.C. (1994).

8. Chou, H. Y., Decision Models for Contractor's Risk Handling in Construction Projects, Department of Civil Engineering, National Taiwan University, Taipei, R.O.C. (2003).

9. Chu, Y. C. and Jhang, S. D., Fuzzy Mathematical Theory and Application, Ru-Lin Books, pp. 183-196 (1991).

10. Committee of Public Project, Edited Cases for Disputes of Government Purchase Contract Execution (I), Taipei, R.O.C. (2001).

11. Erikson, C. A., Risk-Sharing in Construction Contracts, Department of Civil Engineering, University of Illinois at Urbana-Champaign, Illinois, U.S.A. (1979).

12. Guo, J. Y. and Tseng, G. H., "Characteristics and application of analytical hierarchy process (AHP) (I)," Journal of the Chinese Statistical Association, Vol. 27, No. 6, pp. 5-22, (1987).

13. Hsieh, H. M. and Wang, L. C., "A study on performance measurement of mass rapid transit system with fuzzy/AHP Method," Proceedings of the 4th Academic Seminar on Inter-Campus Transportation, pp. 149-162 (1995).

14. Ku, M. C., Risk Allocation and Common Disputes of Construction Contracts, Institute of Technology Law, National Chiao Tung University, Hsinchu, Taiwan, R.O.C. (2003).

15. Lai, S. S., "Contract risk-sharing," Proceedings of the Seminar on Major Construction Management, pp. VIII1-VIII28 (1992).

16. Lee, T. C., "Mediation and arbitration of contract disputes in public projects," Proceedings of the Chinese Institute of Civil and Hydraulic Engineering 1997 Annual Conference, pp. 197-217 (1997).

17. Lee, T. C. and Lee, T. H., "Performance evaluation for construction contract risk-sharing," Proceedings of the 1st Academic Seminar of the Republic of China on Construction Management, pp. III-1-III-10 (1999).

18. Lee, T. C. and Lee, T. H., "Risk and management of contract in public projects," Thesis Collection for Seminar of Risk and Insurance in Public Project, Chia-Yi, Taiwan, R.O.C. (2001).

19. Levitt, R. E., Ashley, D. B., and Logcher, R. D., "Allocating risk and incentive in construction," ASCE Journal of the Construction Division, Vol. 106, No. Co3, pp. 297-305 (1980).

20. Lin, C. Y., Theory of Civil Law and Study on Problems, Rui-Shin Bookstore, pp. 193-195 (1991).

21. Lu, M. Y. and Guo, S. H., Improvement on Adjustment of Material and Wages for Construction Projects, Research Report on Consigned Project from Public Construction Supervision Conference (1992).

22. Mason, G. E., A Quantitative Risk Management Approach to the Selection of Construction Contract Provisions, Department of Civil Engineering, Stanford University, California, U.S.A. (1973).

23. Wang, P. J., Fuzzy Collection Theory and Application, Shang-Hai Science and Technical Publisher (1983).

24. Yates, A. and Sashegyi, B., Effective Risk Allocation in Major Projects: Rhetoric or Reality?, Institution of Engineers, Australia \& Chamber of Commerce and Industry of Western Australia, Australia (2002). 